\title{
FORMATION OF SOCIAL RESPONSIBILITY OF YOUNG PEOPLE IN THE PROCESS OF OBTAINING HIGHER EDUCATION
}

\author{
Lesia Kolomiiets \\ Vinnytsia Mykhailo Kotsiubynsky State Pedagogical University, Ukraine \\ Galyna Shulga \\ Vinnytsia Mykhailo Kotsiubynsky State Pedagogical University, Ukraine \\ Iuliia Lebed \\ Communal Higher Education Institution «Vinnytsia Humanities Pedagogical College», \\ Ukraine
}

\begin{abstract}
In the article the problem of the formation of social responsibility of young people in the process of obtaining higher education is actualized at the theoretical, normative-legal and empirical level. On the basis of diagnostics and a focus group survey, the importance and lack of implementation of the problem of the formation youth social responsibility in the modern realities of the activities of higher educational institutions was proved. It was found that the work of higher educational institutions on the formation of social responsibility is considered by applicants for higher education not to be systemic, oversaturated with education. It was stated that, in the opinion of applicants for higher education, the process of forming social responsibility will be more effective if they are included in socially responsible activities, familiarize themselves with the opportunity to work alongside socially active citizens, get involved in various projects, gain experience in socially responsible behaviour, and spend meaningful leisure. The foreign and domestic experience of the formation of the social responsibility of youth is analyzed. A description of the author's program of the formation of social responsibility of young people in the process of obtaining higher education is proposed, the testing of which has led to positive dynamics in the state of social responsibility of young people.
\end{abstract}

Keywords: activity principles, institutions of higher education, social responsibility formation program, social responsibility, student youth, young people.

\section{Introduction}

Modern legal acts in the field of social policy, social youth policy, education (Declaration "On the general principles of state youth policy in Ukraine"; Law of Ukraine "On social work with families, children and youth"; Law of Ukraine "On promoting social Law of Ukraine "On Education”, "Regulations on Psychological Service in the Education System of Ukraine”, etc.) fix the necessity and expediency of paying special attention of the Ukrainian state to the issues of 
stimulating and supporting social youth activity, formation of conscious civic position and socially responsible behaviour of the younger generation. These priorities are recognized as challenges of the time due to intensive socio-political and socio-economic transformations, European integration and globalization processes.

The problem of forming social responsibility during student youth study in higher education becomes especially relevant in modern conditions, because the key to success of personal and professional development of future professionals is not only high professional competence, but also a responsible attitude to their professional duties, personal and social maturity. Therefore, the task is to develop effective ways of forming social responsibility of young men and women, to implement the latest pedagogical technologies and programs into the educational activities of higher education institutions, thanks to which it will be possible to strengthen the development of this quality.

The purpose of the article is to substantiate the theoretical and methodological principles and present the results of testing the program of formation of social responsibility of young people in the process of obtaining higher education.

150 young people from among the student youth (average age - 21 years and 1 month), 7 teachers and 3 practical psychologists of higher education institutions took part in the research and experimental work. During the study were used such methods: theoretical (analysis of scientific sources, generalizations, modelling), empirical (testing, focus group survey, experiment), data processing (percentage and comparative analysis; statistical generalizations were performed using Student's t-test).

\section{The Theoretical Background}

In scientific research, the social responsibility of young people is interpreted mainly from the standpoint of a conscious attitude to the requirements of social reality, civic duty, solving social problems, compliance with norms, rules and values, awareness of the consequences for certain social groups and social progress achieving self-actualization, personal and social maturity, professional success. In the context of scientific research, O. Bezrukova (2015), L. Dementiy (2005), K. Muzdyibaev (2010), M. Savchyn (2008) and others analyzed the content, features, and factors of social responsibility. M. Viievska (2016), O. Kovalenko (2018), O. Kovalchuk, O. Kantsirenko (2018), O. Kocherga (2012), T. Lunkin (2015, 2018), V. Savelieva (2013), O. Shevchuk, S. Shevchuk (2013) and others studied problems of social responsibility, person's social maturity of different ages, including youth. 
The formation of personal qualities of young men and women, the experience of their responsible behaviour depend on the social space (microsociety, mesosociety and macro-society) in which they are. Striving for selfidentification, young men and women continue to reflect, immerse themselves, reconsider their essential and worldviews about the environment and their own "I", build a subjective sense of the world, life perspective, develop a vision of their own life path. Such worldview changes encourage the emergence of important age-related neoplasms, among which social responsibility occupies an important place. Social responsibility should be understood as an integral personal quality that reveals the interdetermination of relations between the social subject and the social surrounding, a quality which is characterized by the requirement of observance of rights and responsibilities, compliance with social norms and relies on conscious mechanisms of socialization, social identification, social reflection, value-motivational and cognitive resources of the individual, the quality that is reflected in person's behaviour, activities and communication.

In accordance with the formulated goal, we need to analyze the technologies, conditions, methods, tools, forms of work proposed and tested by other researchers in terms of the formation of youth social responsibility.

Scientists from developed countries (S. Kvasničková (2014), L. WrayLake \& A. Syvertsen (2011), L. Jucá, F. Bayma de Oliveira, M. Pires \& A. Sant'Anna (2017)) consider that the formation of students' social responsibility will be facilitated by participation in socially responsible activities, projects, if it is significant, useful for students; modelling of pro-social behaviour in the classroom, the practice of socially responsible behaviour; work in student organizations that engage in social practice.

O. Shylova's (2009) research is about the resource of educational work, in which teachers' efforts should be aimed at developing a number of personal qualities, formations (awareness, acceptance and observance of norms and rules of social responsibility, acceptance of responsibilities; stimulation of motivation of socially responsible behaviour; stimulating the manifestations of emotional and volitional attitude, self-control, correction of one's own socially responsible behaviour, etc.).

O. Shylova offered for future managers of the tourism sector a special course "Socially responsible personality: psychological and pedagogical aspect" in the format of which was supposed to implement: conversations and debates about the components of morality, conscience, tolerant behaviour; the method of positive example and discussion of public opinion on certain issues; method of execution of orders; role-playing games and educational situations; competition method; method of encouragement; sociogram; methods of self-reflection, etc. As expedient forms of work with students O. Shylova offered psychological and pedagogical training, use of opportunities of self-government, participation in 
socially useful, subject-transforming and research activity (for example, volunteering, nature protection work, participation in various actions of historical and cultural direction, etc.).

O. Doneva's (2014) modelled approach to the formation of components of socially responsible behaviour of students of technological institutions of higher education turned out to be interesting. At the level of organizational and pedagogical conditions, in her opinion, it is advisable to introduce special additional training courses for students, diagnosis of the initial level of their responsibility, forecasting the strategy of social responsibility, implementation of changes in educational policy. At the level of didactic conditions, it is advisable to design a model of interaction between teachers and students to facilitate social responsibility. At the level of individual psychological conditions it is necessary to develop motivation for responsible behaviour, provide students with the necessary support in the process of personal and professional development and improve the instrumental and motivational basis for taking responsibility for their actions. At the level of correctional and developmental conditions, prevention of personal and professional deformations in the field of social responsibility development, formation of experience of social responsibility during training are appropriate.

The formation of social responsibility in students, as noted by O. Doneva, should begin with the acquisition of knowledge about social responsibility, the main categories, norms and rules of socially responsible behaviour. The main efforts of the institution should be aimed at forming motives and aspirations to implement socially responsible behaviour; at development of conscious selfregulation of actions and deeds, decision-making and assessment of their consequences. Emphasis should also be placed on gaining experience of socially responsible behaviour in extracurricular activities (research, cultural, educational, sports and health), in the work of student government, in involvement in the development and management of educational activities of the institution.

The author's approach to the areas of formation of student responsibility is presented in the publication of T. Lunkina \& T. Karatai (2015). It consists in the active involvement of young men and women in socially useful activities - charity events, volunteer projects, training programs and volunteer schools, the activities of special centres, festivals, away concerts and more. Demonstration by a higher education institution of examples of socially responsible behaviour and active involvement of students in their implementation is considered a guarantee of the formation of qualities of responsibility in each individual member of the youth. T. Lunkina, T. Karata justified the feasibility of developing a "Regulation on social responsibility" for higher education institutions, which would direct the work on the development of social responsibility of agricultural students in 3 areas: organizational and methodological (creation of a coordinating unit at the 
institution level); practical (creation at the level of faculties of committees on environmental issues, cooperation with public organizations, executive bodies, etc.); propaganda (implementation of projects at the level of student government).

M. Viievska's (2016) publication presents the technology of forming a value attitude to social responsibility of students of economic institutions of higher education. The process of formation of social responsibility, according to M. Viievska, should be aimed at gaining knowledge, gaining experience, stimulating emotional and value experience of attitude to socially responsible behaviour. The scientist emphasized the need for a clear integration of the process of formation of social responsibility and training of future economists, in which social responsibility should develop as a professionally significant quality. M. Viievska considers interactive methods (moderation, mutual learning, group discussion, dialogue, intelligence maps, Balint sessions, etc.) to be effective methods in the implementation of the technology of forming a value attitude to social responsibility.

Researcher O. Kovalenko (2018) developed and tested the pedagogical conditions for the development of social responsibility of residents. The formative experiment was based on the developed special course "Socio-psychological foundations of professional activity", the approbation of which led to an increase in professional and psychological culture, the formation of social responsibility in the system "doctor - patient" (Kovalenko, 2018). One of the effective methods of developing social responsibility of residents, as shown by the experiment O. Kovalenko, was the method of social design of health care programs at the community level in the format of educational, preventive, health projects on healthy living and disease prevention. According to O. Kovalenko, students' formation of social responsibility (future physicians' responsibility) is facilitated by their specific activities, in which the components of socially responsible behaviour are developed during their studies.

Thus, as can be seen from the analysis of publications on the development of youth social responsibility in higher education institutions, scientists propose to introduce additional thematic special courses and training courses, use interactive methods of work, to involve student government resources. Particular emphasis is placed on modelling the conditions in which students would have the opportunity to show social responsibility by joining specific events, actions, volunteering.

\section{Methodology, Organization and Results of the Research}

The practical part of the study of the problem of formation of social responsibility of young people in the process of obtaining higher education took 
place from October 2019 to June 2020 during several stages - ascertaining and formative.

At the first (ascertaining) stage, testing of the study sample $(n=150)$ was performed using the method of "Social Responsibility Scale" by L. Berkowitz and K. Lutterman (according to K. Muzdyibaev). Processing of test data showed the level of formation of social responsibility of boys and girls, who served as an important diagnostic indicator for the organization of experimental work at the formative stage.

Since the purpose of the research was to develop effective principles that would contribute to the formation of youth social responsibility, we thought it would appropriate to find out exactly how from students' point of view such work should be organized in a higher education institution. To this end, at the ascertaining stage of the study, a focus group survey was conducted with 3 groups of applicants for higher education (12 students of 3-4 courses of higher education institutions of different profiles of educational activity).

Processing of test data by the method of "Social Responsibility Scale" by L. Berkowitz and K. Lutterman (according to K. Muzdyibaev) showed the presence of half of the studied boys and girls (students of higher education) signs of situational social responsibility (48\%), indicating social infantilism of their personality, lack of independence, impulsiveness and lack of effort to predict the consequences of their own social actions, lack of self-criticism and propensity for self-justification in different life situations depending on the circumstances, the presence of value conflict, etc. That is, it is likely that depending on life circumstances, the complexity of the situation, the need and extent of social responsibility in boys and girls will decrease.

$25 \%$ of respondents have a high level of social responsibility, which is a feature of their personality. Such representatives of youth are internal, aware of the need for social responsibility, correlate their decisions with the internal structure of social values, norms and rules, moral guidelines, accept the norms and values of the social group, consider themselves responsible for the actions taken and their consequences both for their own lives and for the lives of others.

Empirical data showed that $27 \%$ of the sample showed signs of socially irresponsible behaviour, externality in terms of social responsibility. Such young men and women do not realize and are not convinced that socially responsible behaviour is the key to social stability; they do not have an internal system of social norms and values, or they do not consider themselves able to make decisions, to take responsibility for their possible consequences. 
At the same time, the focus group survey allowed to make the following generalizations:

1) social responsibility is recognized as an important quality in modern society on which depends social (economic, political) stability, social progress, professional realization;

2) social responsibility is correlated with knowledge and observance of social norms, rules, laws, requirements, fulfillment of duty to the family and other social groups (student group, professional community, sorority) and society in general, tolerant behaviour;

3 ) it is indicated that the efforts of the educational institution are more focused on training, organization of extracurricular activities in the specialty (conferences, meetings with specialists, excursions to institutions and organizations where employment is possible, etc.), formation of professional competence during theoretical training and practice;

4) the need for the formation of social responsibility during higher education is evidenced, it is noted that it is satisfied in part, not systematically, sporadically. Students mention the content of some academic disciplines (for example, jurisprudence, political science, sociology, etc.), thematic educational classes, patriotic events, activities to improve the legal culture, the formation of the need for a healthy lifestyle; they also mention participation in charitable actions to help soldiers, orphans and children deprived of parental care; participation in ecological actions on cleaning of the territory of institution and the city as samples of educational activity of higher education institutions on formation of social responsibility;

5) specifies the need to be involved in work that would promote civic competence, develop social responsibility; the majority of students recognize the readiness to work systematically and systematically in this direction; it is considered insufficient to inform exclusively about social responsibility, it is uninteresting to listen to lectures on various aspects of social responsibility;

6) emphasizes the appropriateness of organizing systematic work on the development of social responsibility, the creation of a higher education institution unit that unites teachers, students, other initiative persons, institutions and organizations outside the educational institution, whose joint efforts will be aimed at forming socially responsible behaviour young people through direct involvement in various activities.

From the results of the focus group survey it can be concluded that student youth needs the development of social responsibility, recognizes the need to pay attention to this in the process of obtaining higher education. Focus group 
participants point out the expediency of overemphasis from passive in nature information on the principles of social responsibility of the individual in civil society to provide conditions for direct activities of higher education students to implement socially responsible behaviour, specific actions, actions that reinforce the need and ability to prosocial activity in different life situations.

The study of scientific sources, the study of the state of social responsibility of young people, clarifying the views of young men and women on the need and ways to develop social responsibility convinced the feasibility of developing and testing a program of social responsibility of young people in higher education, which was tested at the second (formative) stage of the study within one year.

The program was attended by young students from higher education institutions, who were included in the experimental groups (EG1 and EG2) and at the ascertaining stage of the study demonstrated situational and low levels of social responsibility. The total number of EG was 37 people. In addition, a control group (CG) of 20 people was established. Before the start of the approbation of the program, the correlation between EG1, EG2 and CG was almost the same in terms of the level of social responsibility (see Table 1).

Table 1 Correlation of EG and CG on the Level of Social Responsibility at the Contact Stage of the Study

\begin{tabular}{|c|c|c|c|}
\hline \multirow{2}{*}{$\begin{array}{c}\text { Levels of social } \\
\text { responsibility }\end{array}$} & EG1 & EG 2 & CG \\
\cline { 2 - 4 } & \multicolumn{3}{|c|}{ number of persons in\% } \\
\hline situational & 56 & 53 & 50 \\
\hline low & 44 & 47 & 50 \\
\hline
\end{tabular}

The program of formation of social responsibility of young people in the process of obtaining higher education was developed taking into account the following key principles and approaches: ensuring the activity approach (creating a productive environment for manifestations of social responsibility); maintenance of subject-subjective interaction (all participants of the program are collaborators, initiators of activity); stimulating the integration of contacts (students cooperation with professional practitioners, public activists from various fields of public practice); production of multidirectional activity (student youth participation in events with ecological, historical, legal, psychological, social, etc. context); integration into the subjective personal and professional experience (building interaction with student youth in the framework of the program, taking into account individual characteristics and the specifics of the chosen specialty); initiating cooperation on the principle of "from equal - to equal" (student youth representatives acted for their peers as coaches, shared experiences, organized activities, etc.). 
Substantiated principles and approaches obtained in the focus group survey, student youth needs were the basis for determining the content and selection of methods, tools and techniques in the implementation of the program of social responsibility of young people in higher education. Preference was given to the use of interactive technologies, involvement of student youth in various actions, projects, participation in training and volunteer work. This format of the program for participants of both EGs provided for the establishment of multilateral communication, maintaining high personal activity, immersion in a real atmosphere of cooperation not only with researchers and psychologists of higher education institutions, but also with practitioners, well-known regional leaders, public figures institutions and institutions of the social sphere (rehabilitation centres for children and youth with disabilities, social services for children and youth, orphanages, geriatric institutions, social service centres, educational institutions, animal shelters, etc.), representatives of volunteer organizations, etc.

Approbation of the program of formation of social responsibility of young people in the process of obtaining higher education for the participants of EG provided for the simultaneous implementation of several content lines:

- participation in various planned events (professional meetings, meetings with famous leaders and public figures, graduates, workshops, webinars, web-quests, etc.);

- $\quad$ inclusion in the project activity (development and implementation of an independent mini-project; involvement in the current project of volunteer, environmental, social and other direction);

- involvement in training sessions on the development of qualities that are important for strengthening personal and social responsibility (stabilization of self-esteem and level of demands, increase of communicative potential, strengthening of self-confidence and selfefficacy, development of goal-setting, self-regulation, empathy, stress resistance and tolerance -semantic sphere, etc.);

- $\quad$ work as a trainer in the format of "from equal - to -equal" with peers, junior students in the context of the problem of individual social responsibility (conducting interactive classes with elements of training, development and presentation of thematic booklets and other printed materials, etc.).

Participation in conferences, round tables, on-line meetings, meetings with well-known leaders and public figures, workshops, webinars, web-quests, etc. were necessary to create opportunities for student youth to look at the problem of social responsibility in society, in terms of implemented efforts, achieved results of activities of individuals or organizations that have led to improved quality of life, improved well-being, meeting the needs of citizens, solving specific 
problems of family, community, environment, etc. It was important to make young people aware and understand that the manifestations of personal initiative and socially responsible behaviour of each individual citizen within their capabilities, abilities, and interests give a real socially significant result, lead to change, level social passivity, stimulate active citizenship. It should be noted that such meetings were held in extracurricular time, and were integrated into the structure of some classes of professional disciplines, which enriches the resources of the educational environment of higher education institutions, strengthens the potential of dual and non-formal student youth education.

The inclusion of EG participants in the project activities within the approbation of the program of formation of social responsibility of young people in the process of obtaining higher education was aimed primarily at the development of specific skills of socially responsible behaviour. It is also worth noting that initially the participants of the program had the opportunity to cooperate (in some cases in on-line format) in the framework of existing projects in rehabilitation centres for children and youth with disabilities, orphanages, NGOs. The topic of the individual project was chosen by the student independently, in some cases taking into account the specialty in which higher education is obtained. The project was developed by each participant of the EG and implemented for the relevant target audience. The involvement of other EG participants in the implementation of the developed project was approved. As projects, the participants of the EG presented videos and social advertising related to current social issues, the need to lead a healthy lifestyle; information and educational campaign and developed booklets for high school students on legal liability; ecological quest to clean the territory from garbage; historical retrospective with a competition of photographs and drawings; volunteer action for orphans, etc. It is appropriate to discuss the developed projects before their implementation in the group with the invitation of experts - professional practitioners.

Training sessions proved to be an important resource for the formation student youth social responsibility during the implementation of the program. This is due to their high reflexive saturation, the use of technology to improve self-knowledge and self-understanding skills, stabilization of self-esteem, awareness of the value of "I" and their own life purpose, feedback and mutual support. Training sessions were built using interactive techniques (brainstorming, case method, group discussion, psychotechnical exercises, energizing exercises, relaxation techniques, reflection tasks, etc.), the work was modelled taking into account the individual characteristics of participants, their needs, dynamics of changes in the state of social responsibility and qualities important for its strengthening. 
The work as a coach in the format of "from equal - to - equal" with peers, junior students in the context of social responsibility of the individual integrates the experience of socially responsible behaviour, actions, intentions, beliefs, creates an opportunity to rethink their conclusions, hear peers, analyze their attitudes to situations of prosocial subjective activity. This role can be performed in different formats: social tutoring; conducting mini-performances with elements of training exercises; social theatre; establishing communication using messengers (Facebook, Telegram, Viber, WhatsApp, Instagram, etc.); organization of web-quests on certain pages on the Internet with the implementation of tasks; blogging, etc. It is worth mentioning that in some places the participants of such meetings were persons, who were involved in individual projects that developed by EG representatives.

The structural components of the developed and tested program of formation of social responsibility of young people in the process of obtaining higher education are summarized in Fig.1.

After the approbation of the program of formation of social responsibility of young people in the process of obtaining higher education, all participants of experimental and control groups were re-tested for the level of social responsibility according to the method of "Social Responsibility Scale" by L. Berkowitz and K. Lutterman (according to K. Muzdyibaev). The results of rediagnosis after completion of the forming phase of the experiment are presented in Table 2.

Table 2 The Results of the Diagnosis of Social Responsibility of Young People after the Completion of the Formative Stage of the Study

\begin{tabular}{|c|c|c|c|}
\hline \multirow{2}{*}{$\begin{array}{c}\text { Levels of social } \\
\text { responsibility }\end{array}$} & EG1 & EG 2 & CG \\
\cline { 2 - 4 } & \multicolumn{3}{|c|}{ number of persons in\% } \\
\hline high & 23 & 26 & - \\
\hline situational & 44 & 37 & 65 \\
\hline low & 33 & 37 & 35 \\
\hline
\end{tabular}

Empirical data shows the presence of dynamics in the state of social responsibility of all members of groups that were created for research and experimental work. However, in both experimental groups, these changes proved to be more productive: the number of young people with low and situational levels of social responsibility decreased; according to the results of diagnosis, students with a high level of social responsibility were identified among the participants of the experimental groups. Thus, it can be assumed that the developed program of social responsibility of young people in the process of obtaining higher education was effective in achieving sustainable positive dynamics in the state of this quality in student youth. The empirical conclusion about the effectiveness of the program 
was confirmed by using Student's t-test. In the process of mathematical and statistical calculations in the program SPSS Statistics v21 it was proved that there are statistically significant differences in the state of social responsibility of young people who participated in the approbation of the program and students of the control group $(\mathrm{t}=3,234$ at $\mathrm{p} \leq 0,01)$.

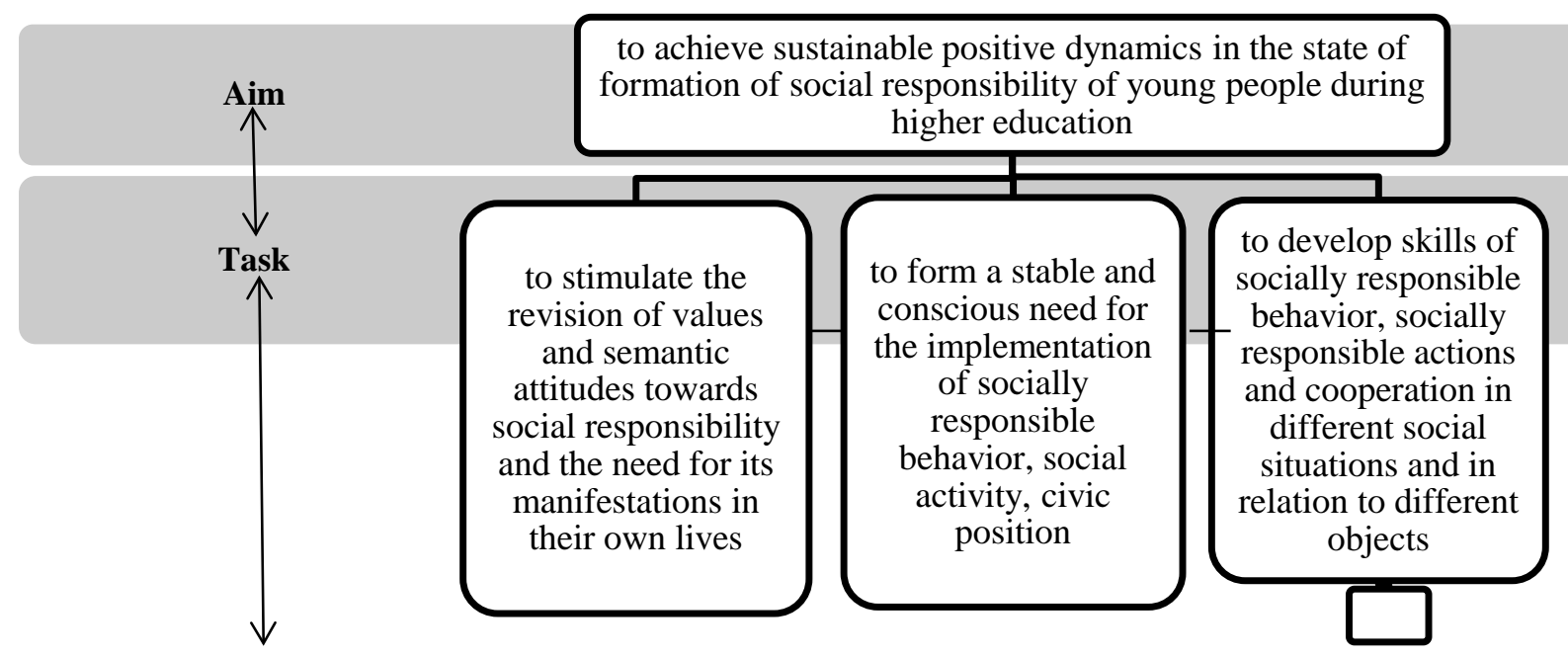

Principles and approaches: providing an activity approach; maintenance of subject-subjective interaction; stimulating the integration of contacts; production of multidirectional activity; integration into subjective personal and professional experience; initiating cooperation on the principle of "from equal - to - equal"

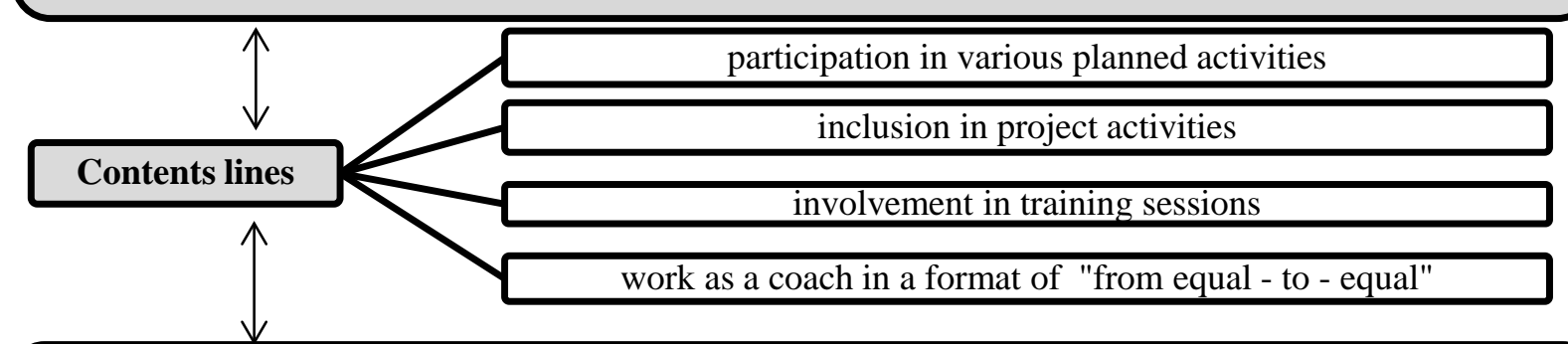

Methods, forms, means: project method, brainstorming, case method, group discussion, training, professional meetings, meetings with famous leaders and public figures, workshops, webinars, web quests, social tutoring, social theatre, blogging, instant messaging, etc.

\section{Figure 1 Structural Components of the Program of Formation of Social Responsibility of Young People in the Process of Obtaining Higher Education}

\section{Conclusions}

Analysis and generalization of theoretical sources, the results of research and experimental work on the approbation of the program of formation of social responsibility of young people in the process of obtaining higher education allowed drawing the following conclusions. 
Social responsibility is an important personal quality, the formation of which in young people is a guarantee of personal and professional self-realization, conscious civic activity and national-patriotic orientation. Young people are sensitive to the formation in the process of primary professionalization of social responsibility and other personal and professional qualities. However, the work of higher education institutions in this direction is unsystematic, overburdened with education, requires restructuring and shifting the emphasis to the active plane.

Approbation of the program of formation of social responsibility of young people in the process of obtaining higher education convinced in expediency of modelling of activity bases of formation of social responsibility of student's youth, involvement of students in participation in concrete social projects and volunteer work during interaction with socially active citizens, integration of professional training and development of important personal and professional qualities in the process of purposeful psychological and pedagogical support.

The long-term effect of the introduction of such changes in the educational policy of higher education institutions is not only the formation of professionally competent and responsible professionals, but also socially active and patriotic citizens, ready to take responsibility and promote civil society institutions, join the life of a particular community, make conscious efforts to achieve social progress.

\section{References}

Bezrukova, O. A. (2015). Sotsialna vidpovidalnist v suchasnomu ukrainskomu suspilstvi: sotsiolohichna kontseptualizatsiia ta dosvid empirychnoho doslidzhennia : dys... dokt. sotsiol. nauk: 22.00.04 - spetsialni ta haluzevi sotsiolohii. Kyiv, 427. [in Ukrainian]

Dementiy, L. I. (2005) Otvetstvennost kak resurs lichnosti: Monografiya. Moskva: InformZnanie, 188. [in Russian]

Doneva, O. V. (2014) Teoreticheskoe obosnovanie modeli razvitiya sotsialnoy otvetstvennosti studentov tehnologicheskogo. Sovremennyie problemyi nauki i obrazovaniya, №3. Dostupno: http://www.science-education.ru/ru/article/view?id=13528. [in Russian]

Jucá, L., Bayma de Oliveira, F., Pires, M., \& Sant’Anna, A. (2017). Valorização do tema "Responsabilidade Social” em instituições de ensino superior? Análise de cursos de administração no estado do Rio de Janeiro. Cadernos EBAPE. BR, 15, 462-481. http://dx.doi.org/10.1590/1679-395160284.

Kovalchuk, O. S. \& Kantsyrenko, O. V. (2016). Vzaiemozviazok sotsialnoi vidpovidalnosti yak tsinnosti z psykholohichnym blahopoluchchiam ukrainskoi molodi. Orhanizatsiina psykholohiia. Ekonomichna psykholohiia, № 1, 37-44. Retrieved from: http://nbuv.gov.ua/UJRN/ophep_2016_1_6. [in Ukrainian]

Kovalenko, E. I. (2018) Razvitie sotsialnoy otvetstvennosti ordinatorov meditsinskogo vuza : dis. ... kand. ped. nauk : 13.00 .08 - teoriya i metodika professionalnogo obrazovaniya. Surgut, 232. [in Russian] 
Kolomiiets et al., 2021. Formation of Social Responsibility of Young People in the Process of Obtaining Higher Education

Kvasničková Stanislavská, L. et al. (2014). “Social Responsibility of Higher Educational Institutions - the Comparison of the View of Students and Potential Students". Journal on Efficiency and Responsibility in Education and Science, Vol. 7, No. 3-4, 95-99. DOI: https://doi.org/10.7160/eriesj.2014.070308.

Lunkina, T. I. (2018). Formuvannia sotsialnoi vidpovidalnosti u vyshchykh navchalnykh zakladakh. Naukovyi visnyk Khersonskoho derzhavnoho universytetu, Seriia Ekonomichni nauky, 145-147. [in Ukrainian]

Lunkina, T. I., \& Karatai, T. M. (2015) Osnovni napriamy rozvytku sotsialnoi vidpovidalnosti u vyshchykh navchalnykh zakladakh. Naukovi pratsi Chornomorskoho derzhavnoho universytetu imeni Petra Mohyly kompleksu "Kyievo-Mohylianska akademiia". Seriia: Ekonomika, T. 265, Vyp. 253, 100-105. Retrieved from: http://nbuv.gov.ua/ UJRN/Npchduec_2015_265_253_19. [in Ukrainian]

Muzdyibaev, K. (2010). Psihologiya otvetstvennosti. Sankt-Peterburg : Izd-vo Knizhnyiy dom "LIBROKOM", 238. [in Russian]

Savchyn, M. V. (2008). Psykholohiia vidpovidalnoi povedinky: monohrafiia. Ivano-Frankivsk: Misto NV, 280. [in Ukrainian]

Savelieva, V.S. (2013). Formuvannia sotsialnoi vidpovidalnosti u studentiv-menedzheriv u tekhnichnomu universyteti. Visnyk NTUU "KPI". Filosofiia. Psykholohiia. Pedahohika, № 2, 69-70. Retrieved from: http://nbuv.gov.ua/UJRN/VKPI_fpp_2013_2_36. [in Ukrainian]

Shevchuk, O. S., Shevchuk, S. P. (2013). Sotsialna vidpovidalnist yak skladova profesiinoi pidhotovky maibutnoho psykholoha. Psykholohichni nauky: zb. nauk. Prats, Vyp. 2, 264268. Retrieved from: http://nbuv.gov.ua/UJRN/Nvmdups_2014_2.13_47. [in Ukrainian]

Shylova, O., (2009). Protses formuvannia sotsialnoi vidpovidalnosti maibutnikh menedzheriv turystychnoi sfery. Naukovi zapysky Ternopilskoho natsionalnoho pedahohichnoho universytetu. Ser.: Pedahohika, №2, 63-69. [in Ukrainian]

Viievska, M. H. (2016). Tekhnolohiia formuvannia tsinnisnoho stavlennia do sotsialnoi vidpovidalnosti u studentiv ekonomichnoho vuzu. Naukovi zapysky. Seriia Pedahohika, №2, 269-275. Retrieved from: http://dspace.tnpu.edu.ua/bitstream/123456789/6925/1/ VIEVSKA.pdf. [in Ukrainian]

Wray-Lake, L., \& Syvertsen, A. (2011). The developmental roots of social responsibility in childhood and adolescence. In C. Flanagan \& B. Christens (Eds.), Youth development: Work at the cutting edge. New Directions for Child and Adolescent Development, 134, 11-25. Retrieved from https://www.researchgate.net/publication/51858309_ 